\title{
Augmentation of Antioxidant Status in the Liver of Swiss Albino Mice treated with Jamun (Syzygium Cumini, Skeels) Extract before Whole Body Exposure to Different Doses of Y-Radiation
}

\author{
Ganesh Chandra Jagetia ${ }^{1 *}$ and Prakash Chandra Shetty ${ }^{2}$ \\ ${ }^{1}$ Department of Zoology, Mizoram University, Aizawl-796 004, India \\ ${ }^{2}$ Department of Anatomy, Melaka Manipal Medical College, Manipal-576 004, India
}

Received: August 31, 2016; Accepted: September 17, 2016; Published: September 20, 2016

*Corresponding author: Ganesh Chandra Jagetia, Professor, Mizoram University, Tanhril, Aizawl-796 004, Mizoram, India, Tel: +011-389-233724; Fax: +011-389-233227; E-mail: gc.jagetia@gmail.com

\begin{abstract}
The ability of ionizing radiations to produce free radicals leads to increased oxidative stress and negative alteration of the antioxidant status in the exposed organisms. The increased oxidative stress is responsible for the induction of various deleterious effects of ionizing radiation. The introduction of phytoceuticals may reduce the radiation-induced oxidative stress. Therefore present study was designed to study the effect of oral administration of $50 \mathrm{mg} / \mathrm{kg}$ body weight of Jamun (Syzygium cumini) leaf extract on the antioxidant status in the liver of mouse exposed to $0,0.5,1,2,3$ or 4 Gy whole body $\gamma$-radiation. Irradiation of mice to different doses of $\gamma$-radiation caused a significant and dose dependent decline in the glutathione concentration, catalase and superoxide dismutase activities at $0.51,2,4,8,12$ and $24 \mathrm{~h}$ post-irradiation. A maximum decline in glutathione concentration was observed at $1 \mathrm{~h}$ post-irradiation, whereas superoxide dismutase activity showed a highest decrease at $2 \mathrm{~h}$ post-irradiation. In contrast lipid peroxidation increased in a dose dependent manner at all post-irradiation times with a greatest rise at $2 \mathrm{~h}$ post-irradiation in the animals exposed to $4 \mathrm{~Gy}$. Administration of mice with jamun extract before exposure to 0- 4 Gy resulted in a significant elevation in the glutathione concentration and catalase and superoxide dismutase activities at all exposure doses, whereas lipid peroxidation reduced significantly when compared with the irradiated group that did not receive jamun extract at all postirradiation times. Our study demonstrates that treatment of mice with jamun extract elevated the antioxidant status and reduced the radiation-induced oxidative stress in mouse liver.
\end{abstract}

Keywords: Mice; Radiation; Jamun; Glutathione; Catalase; Superoxide dismutase; Lipid peroxidation

\section{Introduction}

The increasing power need of the world can be met by installing nuclear power generators. However, nuclear power generation comes with a price of undesired human exposure to ionizing radiations due to increase in the back ground radiation in the vicinity of these generators. This may be compounded during nuclear accidents and or leakage of radioactivity in the environment. The Chernobyl accident has not only exposed the biota including humans in its vicinity but also irradiated the far flung areas due to massive release of radioactivity during this catastrophe leading to several physiological and genetic effects [1]. Further exposure of flora and fauna during this disaster has led to the contamination of consumable products therefore covering large human population [2]. The recent accident at Fukushima nuclear power plant in 2011 had also led to similar effects in the form of physiological, genetic, developmental and fitness effect in non-human population [3]. The exposure to low level radiation has become common due medical diagnostic and therapeutic procedures, frequent space or air travel, cosmic radiation and use of certain electronic gadgets. Other sources of radiation exposure include radon in houses, contamination from weapon testing sites, and unexpected terrorist attacks [4-7].

Ionizing radiation consists of energetic particles and electromagnetic radiation, which can penetrate living tissues or cells and transfer energy to the biological materials. This interaction of ionizing radiation with cells results in the production of ionization, free radical generation, chemical bond breakage, and oxidative stress $[8,9]$. These free radicals inturn react with important macromolecules including nucleic acids, membrane lipids, and proteins leading to their structural alteration [10-12]. This molecular alteration induced by ionizing radiation causes mutations, chromosomal aberrations and carcinogenesis or cell death $[12,13]$. The Oxidative Stress (OS) is a state of imbalance between generation of ROS and the level of antioxidant defence system. Radiation induced free radicals subsequently impair the antioxidative defence mechanism of a cell, leading to an increased membrane lipid peroxidation, which results in damage to the membrane bound enzymes [14]. It is commonly accepted that under situations of oxidative stress, reactive oxygen species including superoxide, hydroxyl, and peroxyl radicals are generated. OS and free-radical-mediated processes have been implicated in the pathogenesis of a variety of diseases including 
ageing, cancer, coronary heart diseases, neurodegenerative disorders, atherosclerosis, cataracts, inflammation and digestive system disorders [15-17].

Cells are well equipped to defend themselves against ROS, with a repertoire of antioxidant enzymes and molecules $[7,18,19]$. Antioxidant enzymes are part of the endogenous system available for the removal or detoxification of free radicals and their products formed by ionizing radiation [18,20]. The antioxidant system consists of low molecular weight antioxidants like glutathione, melatonin and various antioxidant enzymes including superoxide dismutase, catalase, glutathione peroxidase etc. [21].

Ionizing radiations induce additional oxidative stress in the irradiated organisms and the indigenous antioxidants of cells may not be able to neutralize this additional burden alone. The supplementation of exogenous substance may be required to combat the additional oxidative stress in the irradiated system [7,20-22]. The phytoceuticals may be of great use to combat the additional oxidative stress in the irradiated system or even otherwise. Jamun, Syzygium cumini Linn. Skeels (family Myrtaceae) is a medium sized to large tree. It has been reported to possess several medicinal properties in the folklore and Ayurvedic systems of medicine. The stem bark of jamun is astringent, anthelmintic, antibacterial, carminative, constipating, diuretic, digestive, febrifuge, refrigerant, stomachic and sweet. The fruits and seeds are used to treat diabetes, and splenopathy [23]. Jamun has been reported to be antioxidant, anti-inflammatory, antibacterial, anticancer, antidiabetic, antiviral, antifungal, antidiahorreal, antileishmanial, chemopreventive, hypoglycemic and gastro protective [24-31]. The leaf extract of jamun has been found to scavenge different free radicals in vitro [32]. The studies from our laboratory has indicated that the leaves of the jamun have reduced the radiation-induced DNA damage in the cultured human peripheral blood lymphocytes as well as mouse splenocytes [32,33]. Its leaf and seed extract have been reported to increase the survival of irradiated mice and it also protected against radiation-induced gastrointestinal injury [34-36]. The presence of different activities in jamun stimulated us to obtain an insight into the antioxidant status of jamun (Syzygium cumini, Skeels) leaf extract in the liver of mice whole body exposed to different doses of $\gamma$-radiation.

\section{Materials and Methods}

\section{Animal care and Handling}

The animal care and handling were carried out according to the guidelines issued by the World Health Organization, Geneva, Switzerland and the INSA (Indian National Science Academy, New Delhi, India). Usually ten to twelve weeks old male Swiss albino mice weighing 30 to $36 \mathrm{~g}$ were obtained from an inbred colony maintained under the controlled conditions of temperature (23 $\left.\pm 2^{\circ} \mathrm{C}\right)$, humidity $(50 \pm 5 \%)$ and light $(14$ and $10 \mathrm{~h}$ of light and dark, respectively) in the institutional animal house. The animals were allowed free access to the sterile water and food. Usually, four animals were kept in a polypropylene cage containing sterile paddy husk (procured locally) as bedding throughout the experiment. The study was approved by the Institutional Animal Ethical Committee.

\section{Chemicals}

Analytical grade cumene hydroperoxide, thiobarbituric acid (TBA), ascorbic acid, glutathione (GSH), 5,5-dithio-bis (2-nitrobenzoicacid) (DTNB), diethylenetriaminepentaaceticacid (DTPA), butylated hydroxytolune, 1-chloro-2,4-dinitrobenzene, 2,4- dinitrophenyl hydrazine, guanidine hydrochloride, ferric chloride, ferrous sulphate and tetraethoxypropane were procured from Sigma Chemicals Co, St. Louis, MO, USA. The routine chemicals were supplied by Merck India, Mumbai.

\section{Preparation of the Extract}

The fresh mature leaves of jamun (Syzygium cumini Linn. Skeels or Eugenia cumini Linn. Druce), family Myrtaceae were collected locally during the month of May. The tree was identified by Dr. G.K. Bhat (Department of Botany, Poorna Prajna College, Udupi, Karnataka, India) a well-known taxonomist of the region. The leaves were cleaned, dried in shade, and powdered in a mixer grinder and extracted as described earlier [37]. Briefly, the leaf powder was extracted in petroleum ether and chloroform and finally in $1: 1$ dichloromethane and methanol at $50-60^{\circ} \mathrm{C}$ using a Soxhlet apparatus. The extract was cooled and concentrated by evaporating its liquid contents in vacuo and freeze dried. The extract was stored at $-70^{\circ} \mathrm{C}$ until further use. Henceforth the extract of Syzygium cumini will be called as SCE.

\section{Preparation of drug and mode of Administration}

The required amount of SCE was dissolved in $1 \%$ carboxymethyl cellulose (CMC) in sterile double distilled water immediately before use. The animals were administered orally with SCE or CMC, consecutively for 5 days.

\section{Experimental}

The effect of leaf extract of jamun was studied in the liver of irradiated mice dividing them into the following groups:-

\section{CMC + irradiation}

The animals of this group were administered with $0.01 \mathrm{ml} / \mathrm{g}$ body weight of CMC orally before irradiation to $0,0.5,1,2,3$ or 4 Gy.

\section{SCE + irradiation}

The animals of this group were administered with $50 \mathrm{mg} / \mathrm{kg}$ body weight SCE orally once daily for 5 consecutive days before exposure to $0,0.5,1,2,3$ or 4 Gy of $\gamma$-radiation [32].

\section{Irradiation}

One hour after the last administration of CMC or SCE on $5^{\text {th }}$ day, the prostrate and immobilized animals (achieved by inserting cotton plugs in the restrainer) were whole body exposed to $0,0.5$, 1, 2, 3 or $4 \mathrm{~Gy}$ of ${ }^{60} \mathrm{Co}$ gamma radiation (Theratron, Atomic Energy Agency, Canada) in a specially designed well-ventilated acrylic box. A batch of twelve animals was irradiated each time at a dose rate of $1.66 \mathrm{~Gy} / \mathrm{min}$ at a SSD of $100 \mathrm{~cm}$. 


\begin{tabular}{|l|l|l|l|l|l|l|l|}
\hline Grouping & Treatment & \multicolumn{5}{|c|}{ Exposure dose (Gy) } \\
\hline CMC+irradiation & $\begin{array}{l}1 \% \\
\text { Carboxymethylcellulose }\end{array}$ & 0 & 0.5 & 1 & 2 & 3 & 4 \\
\hline SCE+irradiation & $\begin{array}{l}\text { 50 mg/kg Jamun extract } \\
\text { (SCE) }\end{array}$ & 0 & 0.5 & 1 & 2 & 3 & 4 \\
\hline Post irradiation assay time (h) for each group & 0.5 & 1 & 2 & 4 & 8 & 12 & 24 \\
\hline
\end{tabular}

\section{Experimental design}

Note: 4 animals were used at each post-irradiation time $(0.5,1,2,4,8,12$ and $24 \mathrm{~h})$ that is 28 animals for each exposure dose in each group. In other words 28 animals were used for each exposure dose in each group 28X6 (0, 0.5,1,2,3, and 4 Gy) = $168 \mathrm{X} 2$ (CMC+irradiation and SCE+irradiation), which equals to 336 animals for the whole experiment.

\section{Preparation of liver Homogenate}

The animals from each group were euthanized at $0.5,1,2,4$, 8,12 and $24 \mathrm{~h}$ post-irradiation and their livers were perfused transcardially with ice cold phosphate buffered saline. The whole liver from each animal was removed, blot dried, weighed and a $10 \%$ homogenate was prepared in ice-cold $0.2 \mathrm{M}$ sodium phosphate buffer Ph 8.0 using a homogenizer (Yamato LSG LH21, Tokyo, Japan). Four animals were used for each irradiation dose at each time interval in all concurrent groups and a total of 336 animals were used for the entire study.

\section{Total proteins}

The protein contents were determined using the modified method of Lowry.

\section{Glutathione}

Glutathione (GSH) contents were measured as described by Moron et al. [38]. Briefly, proteins were precipitated by 25\% TCA, centrifuged and the supernatant was collected. The supernatant was mixed with $0.2 \mathrm{M}$ sodium phosphate buffer ( $\mathrm{pH} \mathrm{8.0)}$ ) and $0.06 \mathrm{mM}$ DTNB followed by incubation for $10 \mathrm{~min}$ at room temperature. The absorbance of the sample/s was read against the blank at $412 \mathrm{~nm}$ in an ultraviolet-visible light (UV-VIS) double beam spectrophotometer (UV-260; Shimadzu Corporation, Tokyo, Japan) and the GSH concentration was calculated from the standard curve, and it has been expressed as $\mu \mathrm{mol} / \mathrm{g}$ tissue.

\section{Catalase}

Catalase activity was determined by catalytic reduction of hydrogen peroxide [39]. Briefly, hydrogen peroxide was added to the sample and the mixture was incubated at $37^{\circ} \mathrm{C}$. Catalase activity was measured by recording the decrease in absorbance at $240 \mathrm{~nm}$ periodically after addition of sample in a UV-VIS spectrophotometer. The average difference in absorbance in 30 sec was calculated. A unit of catalase is defined as the amount of protein that results in a decrease in absorbance of $0.05 \mathrm{in} 30 \mathrm{sec}$.

\section{Superoxide dismutase}

The SOD was estimated by the method of Fried [40]. Briefly, $900 \mu \mathrm{l}$ buffer was mixed with $100 \mu$ tissue homogenate (T), nitroblue tetrazolium (NBT), phenazine methosulphate and
NADH. The control (C) consisted of all the reagents except the homogenate, whereas, the blank (B) consisted of buffer and the homogenate without any reagents. The absorbance of $\mathrm{T}, \mathrm{C}$ and $\mathrm{B}$ was read at $560 \mathrm{~nm}$ using a UV-Visible spectrophotometer and the enzyme activity has been expressed in units $(1 \mathrm{U}=50 \%$ inhibition of NBT reduction).

\section{Lipid peroxidation}

Lipid peroxidation (LOO) was measured according to the standard protocol [41]. Briefly, the samples were incubated with a mixture of trichloroacetic acid (15\%), thiobarbituric acid $(0.375 \%)$, and butylated hydroxytoluene $(0.01 \%)$ in $0.25 \mathrm{~N} \mathrm{HCl}$ at $95^{\circ} \mathrm{C}$ for $25 \mathrm{~min}$. The reaction mixture was cooled to room temperature and centrifuged at 8,000 g. The supernatant was collected and the absorbance was recorded against the blank using a double beam UV-VIS spectrophotometer. The LOO was measured from a standard curve and has been expressed as MDA in $\mathrm{nM}$ per mg protein.

\section{Analysis of data}

The statistical significance among various groups was determined using ANOVA or student-' $t$ ' test wherever necessary. Graph Pad statistical package (Graph Pad software, San Digeo, USA) was used for data analysis. All the data are expressed as mean and standard error of the mean (SEM).

\section{Results}

The results are expressed as GSH concentration ( $\mu \mathrm{mol} / \mathrm{g}$ tissue), catalase activity ( $\mu \mathrm{mol} / \mathrm{mg}$ protein), superoxide activity (U/mg protein) and lipid peroxidation (nM/mg protein) \pm SEM (standard error of the mean) in Table [1-4] and Figures[1-8].

\section{Glutathione}

The reduced glutathione (GSH) concentration was determined in mouse liver at different post-irradiation times. The normal baseline GSH level in CMC (0 Gy) treated mice ranged between $4.18 \pm 0.05$ to $4.23 \pm 0.06 \mu \mathrm{mol} / \mathrm{mg}$ tissue. Administration of $50 \mathrm{mg} / \mathrm{kg}$ SCE (0 Gy) orally for five consecutive days did not induce significant change in GSH concentration when compared to normal baseline concentration ( $4.2 \pm 0.05$ to 4.3 \pm 0.05 ). Exposure of animals to different doses of $\gamma$-radiation resulted in a dose dependent decrease in the GSH concentration when compared with normal baseline GSH concentration of CMC+sham-irradiation (Figure 1). The GSH concentration declined at $0.5 \mathrm{~h}$ post-irradiation with a maximum decline at 1 h post-irradiation after 4 Gy irradiation, where an almost 2 fold decline in GSH concentration was observed. Thereafter the GSH concentration showed a gradual rise until $24 \mathrm{~h}$ post-irradiation however, normal levels could not be attained (Figure 2). The GSH concentration was significantly $(p<0.001)$ lower when compared to $\mathrm{CMC}+$ sham-irradiation ( $0 \mathrm{~Gy}$ ). The comparison among different doses of radiation revealed that the GSH concentration was significantly reduced with increasing dose of radiation $(p<0.05$; 0.01 or 0.001 ) depending on the irradiation dose and estimation time (Table 1). The pattern of decline in GSH concentration after 
Table 1: The effect of jamun (SCE) pre-treatment on the radiation-induced alteration in glutathione levels in liver of mouse exposed to different doses of $\gamma$-radiation.

\begin{tabular}{|c|c|c|c|c|c|c|c|c|c|c|c|c|c|c|}
\hline \multirow{3}{*}{$\begin{array}{l}\text { Dose } \\
\text { (Gy) }\end{array}$} & \multicolumn{14}{|c|}{ Post-irradiation time (hours) } \\
\hline & \multicolumn{2}{|l|}{0.5} & \multicolumn{2}{|l|}{$\mathbf{1}$} & \multicolumn{2}{|l|}{2} & \multicolumn{2}{|l|}{4} & \multicolumn{2}{|l|}{8} & \multicolumn{2}{|l|}{12} & \multicolumn{2}{|l|}{24} \\
\hline & CMC+IR & SCE+IR & CMC+IR & SCE+IR & CMC+IR & SCE+IR & CMC+IR & SCE+IR & CMC+IR & SCE+IR & CMC+IR & SCE + IR & CMC+IR & SCE+IR \\
\hline 0 & $4.23 \pm 0.06$ & $4.3 \pm 0.05$ & $4.09 \pm 0.05$ & $4.2 \pm 0.05$ & $4.19 \pm 0.02$ & $4.17 \pm 0.05$ & $4.23 \pm 0.02$ & $4.06 \pm 0.05$ & $4.16 \pm 0.02$ & $4.3 \pm 0.05$ & $4.08 \pm 0.02$ & $4.28 \pm 0.05$ & $4.18 \pm 0.05$ & $4.2 \pm 0.05$ \\
\hline 0.5 & $3.81 \pm 0.08$ & $4.0 \pm 0.08^{*}$ & $3.67 \pm 0.04^{*}$ & $4.15 \pm 0.08^{\mathrm{c}}$ & $3.86 \pm 0.08$ & $4.19 \pm 0.08^{\mathrm{b}}$ & $3.96 \pm 0.01$ & $4.06 \pm 0.08$ & $4.01 \pm 0.01$ & $4.15 \pm 0.08$ & $3.98 \pm 0.01$ & $4.16 \pm 0.08$ & $4.01 \pm 0.01$ & $4.18 \pm 0.05$ \\
\hline 1 & $3.49 \pm 0.06^{*}$ & $3.95 \pm 0.03^{\mathrm{sc}}$ & $3.21 \pm 0.02 * *$ & $3.65 \pm 0.03^{\mathrm{c}^{*}}$ & $3.4 \pm 0.01^{\text {** }}$ & $3.72 \pm 0.03^{*}$ & $3.59 \pm 0.09^{*}$ & $3.83 \pm 0.03$ & $3.68 \pm 0.06^{5^{*}}$ & $3.9 \pm 0.03^{\text {b** }}$ & $3.96 \pm 0.06$ & $4.1 \pm 0.03$ & $4.04 \pm 0.06$ & $4.06 \pm 0.03$ \\
\hline 2 & $2.86 \pm 0.09^{5 *}$ & $3.65 \pm 0.05^{* s^{*}}$ & $2.5 \pm 0.09^{*}$ & $3.2 \pm 0.05^{*}$ & $2.64 \pm 0.09^{*}$ & $3.2 \pm 0.06^{6^{*}}$ & $3.09 \pm 0.09 *$ & $3.49 \pm 0.05^{5^{*}}$ & $3.19 \pm 0.09^{*}$ & $3.65 \pm 0.06^{\mathrm{ct*}}$ & $3.42 \pm 0.09^{5 *}$ & $3.87 \pm 0.06^{\mathrm{ct*}}$ & $3.78 \pm 0.09^{\mathrm{s}}$ & $3.93 \pm 0.06^{5}$ \\
\hline 3 & $2.69 \pm 0.15^{*}$ & $3.21 \pm 0.06^{\mathrm{b}^{*}}$ & $2.43 \pm 0.15^{*}$ & $3.16 \pm 0.06^{\mathrm{c}^{*}}$ & $2.52 \pm 0.15^{*}$ & $3.18 \pm 0.05^{*}$ & $2.99 \pm 0.15^{5 *}$ & $3.42 \pm 0.06^{\mathrm{b}^{*}}$ & $2.89 \pm 0.05^{* *}$ & $3.61 \pm 0.02^{5^{*}}$ & $3.01 \pm 0.15^{*}$ & $3.64 \pm 0.05^{*}$ & $3.45 \pm 0.05^{5 *}$ & $3.78 \pm 0.01^{5 *}$ \\
\hline 4 & $2.46 \pm 0.08^{*}$ & $2.95 \pm 0.04^{* c^{*}}$ & $2.21 \pm 0.08^{*}$ & $2.81 \pm 0.04^{5 \mathrm{c}^{*}}$ & $2.37 \pm 0.08^{*}$ & $2.95 \pm 0.04^{c^{*}}$ & $2.76 \pm 0.08^{*}$ & $2.97 \pm 0.03^{*}$ & $2.85 \pm 0.05^{5^{*}}$ & $3.16 \pm 0.02^{*}$ & $2.99 \pm 0.08^{* *}$ & $3.54 \pm 0.03^{5^{*}}$ & $3.22 \pm 0.05^{*}$ & $3.56 \pm 0.02$ \\
\hline
\end{tabular}

Table 2: The effect of jamun (SCE) pre-treatment on the radiation-induced Superoxide dismutase activity in liver of mouse exposed to different doses of $\gamma$-radiation. Post-irradiation time (hours)

\begin{tabular}{|c|c|c|c|c|}
\hline $\begin{array}{ll}\text { Ose } & 0.5 \\
\end{array}$ & 1 & 2 & 4 & 8 \\
\hline
\end{tabular}

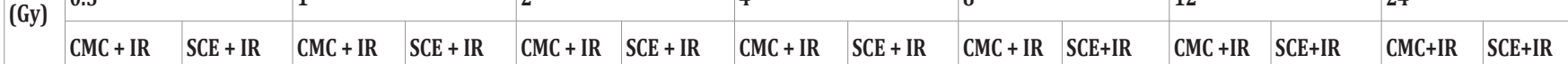

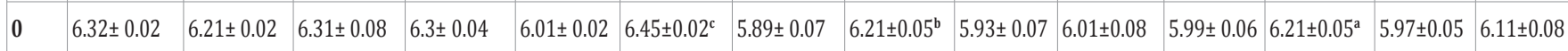

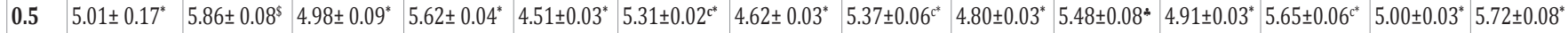

\begin{tabular}{lll|l|l|l|l|l|l|l|l|l|l|l|l|l|l|l}
1 & $4.56 \pm 0.04^{*}$ & $4.98 \pm 0.06^{*}$ & $4.01 \pm 0.09^{*}$ & $4.52 \pm 0.02^{*}$ & $3.62 \pm 0.05^{*}$ & $4.47 \pm 0.04^{*}$ & $3.89 \pm 0.05^{*}$ & $4.64 \pm 0.04^{*}$ & $4.21 \pm 0.06^{*}$ & $4.76 \pm 0.07^{*}$ & $4.65 \pm 0.05^{*}$ & $4.80 \pm 0.04^{*}$ & $4.90 \pm 0.06^{*}$ & $5.10 \pm 0.07^{c^{*}}$
\end{tabular}

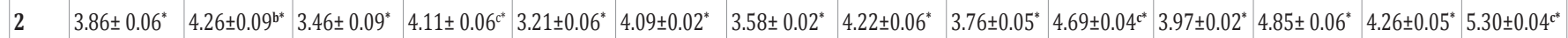

\begin{tabular}{ll|l|l|l|l|l|l|l|l|l|l|l|l|l}
3 & $3.21 \pm 0.07^{*}$ & $3.82 \pm 0.04^{*}$ & $3.02 \pm 0.03^{s^{*}}$ & $3.62 \pm 0.02^{c^{*}}$ & $2.01 \pm 0.06^{*}$ & $3.09 \pm 0.04^{*}$ & $2.68 \pm 0.04^{*}$ & $2.93 \pm 0.07^{*}$ & $3.02 \pm 0.03^{*}$ & $3.24 \pm 0.04^{*}$ & $3.68 \pm 0.04^{*}$ & $3.97 \pm 0.07^{*}$ & $4.21 \pm 0.03^{*}$ & $5.10 \pm 0.04^{*^{*}}$
\end{tabular}

$4 \quad 3.01 \pm 0.06^{*} \quad 3.52 \pm 0.02^{* *} \quad 2.61 \pm 0.04 * * 2.99 \pm 0.06^{c^{*}} \quad 2.02 \pm 0.06^{*} \quad 2.86 \pm 0.07^{7 \mathrm{sc}^{*}} \quad 2.71 \pm 0.02^{*} \quad 3.12 \pm 0.08^{*^{*}} \quad 2.99 \pm 0.04^{*} \quad 3.41 \pm 0.03^{c^{*}} \quad 3.56 \pm 0.02^{*} \quad 4.06 \pm 0.08^{*^{*}} \quad 3.84 \pm 0.04^{*} \quad 4.62 \pm 0.03^{*}$

a: $P<0.05, b: P<0.01, c: P<0.001$, no symbol : non-significant. CMC+IR group compared to SCE+IR

$*: P<0.05, \$: P<0.01, *: P<0.001$, no symbol : non-significant. When compared to Sham-radiation (0 Gy) group

$\mathrm{CMC}=$ Carboxymethylcellulose

IR= Irradiation

SCE $=$ Syzygium cumini extract

\begin{tabular}{|c|c|c|c|c|c|c|c|c|c|c|c|c|c|c|}
\hline \multirow{3}{*}{$\begin{array}{l}\text { Dose } \\
\text { (Gy) }\end{array}$} & \multicolumn{14}{|c|}{ Post-irradiation time (hours) } \\
\hline & \multicolumn{2}{|r|}{0.5} & \multicolumn{2}{|r|}{1} & \multicolumn{2}{|c|}{2} & \multicolumn{2}{|c|}{4} & \multicolumn{2}{|c|}{8} & \multicolumn{2}{|c|}{12} & \multicolumn{2}{|c|}{24} \\
\hline & CMC+IR & SCE+IR & CMC+IR & SCE+IR & CMC+IR & SCE+IR & CMC+IR & SCE+IR & CMC+IR & SCE+IR & CMC + IR & SCE+IR & CMC+IR & SCE+IR \\
\hline 0 & $29.21 \pm 0.25$ & $28.21 \pm 0.45^{a}$ & $29.87 \pm 0.35$ & $27.87 \pm 0.35$ & $29.35 \pm 0.25$ & $29.15 \pm 0.35$ & $28.21 \pm 0.67$ & $28.01 \pm 0.61$ & $29.21 \pm 0.32$ & $28.01 \pm 0.61^{\mathrm{a}}$ & $29.26 \pm 0.66$ & $28.01 \pm 0.61$ & $29.22 \pm 0.22$ & $28.01 \pm 0.62$ \\
\hline 0.5 & $24.21 \pm 0.35^{*}$ & $27.21 \pm 0.65^{c}$ & $23.27 \pm 0.35^{*}$ & $25.21 \pm 0.34^{c \$}$ & $21.21 \pm 0.71^{*}$ & $24.21 \pm 0.35^{*}$ & $23.21 \pm 0.30^{*}$ & $24.12 \pm 0.30^{25}$ & $23.11 \pm 0.75^{*}$ & $25.36 \pm 0.27^{*}$ & $23.21 \pm 0.30^{*}$ & $25.02 \pm 0.30^{c \omega}$ & $23.11 \pm 0.75^{*}$ & $25.16 \pm 0.27^{*}$ \\
\hline 1 & $22.28 \pm 0.34^{*}$ & $23.45 \pm 0.60^{5}$ & $23.58 \pm 0.30^{*}$ & $25.26 \pm 0.32^{\mathrm{bs}}$ & $20.21 \pm 0.39^{*}$ & $22.15 \pm 0.30^{c^{*}}$ & $21.25 \pm 0.51^{*}$ & $23.21 \pm 0.29^{b^{*}}$ & $21.26 \pm 0.28^{*}$ & $23.42 \pm 0.30^{*}$ & $21.15 \pm 0.53^{*}$ & $23.11 \pm 0.22^{*}$ & $21.16 \pm 0.25^{*}$ & $23.12 \pm 0.33^{*}$ \\
\hline 2 & $19.21 \pm 0.75 \$^{*}$ & $22.23 \pm 0.75^{a}$ & $18.12 \pm 0.35^{*}$ & $21.24 \pm 0.35^{c}$ & $17.28 \pm 0.62^{25^{5}}$ & $20.25 \pm 0.75^{b^{*}}$ & $18.21 \pm 0.45^{*}$ & $20.01 \pm 0.75^{\text {aast }}$ & $18.26 \pm 0.85^{*}$ & $21.26 \pm 0.61^{a^{*}}$ & $18.21 \pm 0.45^{*}$ & $20.01 \pm 0.75^{2 a *}$ & $18.26 \pm 0.85^{*}$ & $21.26 \pm 0.61^{t^{*}}$ \\
\hline 3 & $17.96 \pm 0.23^{*}$ & $19.24 \pm 0.35^{b * t}$ & $16.21 \pm 0.78^{\circ}$ & $18.26 \pm 0.47^{*}$ & $16.54 \pm 0.55^{5^{4}}$ & $17.86 \pm 0.35^{5 a^{*}}$ & $17.01 \pm 0.82^{5^{5}}$ & $18.21 \pm 0.75^{*}$ & $17.35 \pm 0.31^{5^{4}}$ & $18.85 \pm 0.32^{b^{*}}$ & $17.01 \pm 0.82^{5^{+}}$ & $18.21 \pm 0.75^{a^{*}}$ & $17.35 \pm 0.31 \$^{*}$ & $18.85 \pm 0.32^{b^{*}}$ \\
\hline 4 & $17.01 \pm 0.42^{* *}$ & $19.21 \pm 0.39^{b^{b *}}$ & $16.24 \pm 0.43^{*}$ & $18.24 \pm 0.41^{b^{*}}$ & $15.21 \pm 0.75^{*}$ & $18.11 \pm 0.66^{b^{*}}$ & $15.84 \pm 0.78^{*}$ & $17.21 \pm 0.67^{*}$ & $16.89 \pm 0.68^{*}$ & $18.93 \pm 0.75^{a^{*}}$ & $15.84 \pm 0.78^{*}$ & $17.21 \pm 0.67^{a^{*}}$ & $16.89 \pm 0.68^{*}$ & $18.93 \pm 0.75^{a^{*}}$ \\
\hline $\begin{array}{l}a: P<0 \\
\because: P<0 . \\
C M C=0 \\
\text { IR }=\text { Irr } \\
\text { SCE }=S\end{array}$ & $\begin{array}{l}05, b: P<0.01 \text {, } \\
05, \$: P<0.01 \text {, } \\
\text { arboxymethylc } \\
\text { adiation } \\
\text { yzygium cumini }\end{array}$ & $\begin{array}{l}1, c: P<0.001, \text { no sy } \\
1, *: P<0.001 \text {, no sy } \\
\text { lcellulose } \\
\text { ni extract }\end{array}$ & ymbol: non-sis & gnificant. CMC+IR & roup compar & ed to SCE+IR & group & & & & & & & \\
\hline
\end{tabular}

treatment with SCE in SCE+irradiation group was identical to that of CMC+irradiation group (Figure 1) except that the SCE administration arrested the radiation-induced decline in the GSH concentration significantly at all post-irradiation times after exposure to 0.5 to 4 Gy (Table 1). However, baseline levels could not be restored even at $24 \mathrm{~h}$ post-irradiation except $0.5 \mathrm{~Gy}$, where it was almost normal (Table 1).

\section{Superoxide Dismutase}

The MnSOD activity was measured in mouse liver at different post-irradiation times and the activity of mitochondrial SOD is expressed as units/ mg protein \pm SEM (Figure 3). The MnSOD 
Augmentation of Antioxidant Status in the Liver of Swiss Albino Mice treated with Jamun (Syzygium Cumini, Skeels) Extract before Whole Body Exposure to Different Doses of $\gamma$-Radiation

Table 4: The effect of jamun (SCE) pre-treatment on the radiation-induced lipid peroxidation in liver of mouse exposed to different doses of $\gamma$ - radiation.

\begin{tabular}{|c|c|c|c|c|c|c|c|c|c|c|c|c|c|c|}
\hline \multirow{3}{*}{$\begin{array}{l}\text { Dose } \\
\text { (Gy) }\end{array}$} & \multicolumn{14}{|c|}{ Post-irradiation time (hours) } \\
\hline & \multicolumn{2}{|c|}{0.5} & \multicolumn{2}{|c|}{1} & \multicolumn{2}{|c|}{2} & \multicolumn{2}{|c|}{4} & \multicolumn{2}{|c|}{8} & \multicolumn{2}{|c|}{12} & \multicolumn{2}{|r|}{24} \\
\hline & CMC+IR & SCE+IR & CMC+IR & SCE+IR & CMC+IR & SCE+IR & CMC+IR & SCE+IR & CMC+IR & SCE+IR & $\mathrm{CMC}+\mathrm{IR}$ & SCE+IR & CMC+IR & SCE+IR \\
\hline 0 & $17.23 \pm 1.25$ & $16.54 \pm 1.21$ & $17.54 \pm 1.04$ & $16.89 \pm 1.32$ & $17.61 \pm 1.32$ & $17.21 \pm 1.51$ & $17.3 \pm 1.74$ & $17.12 \pm 1.62$ & $17.61 \pm 1.04$ & $17.01 \pm 1.61$ & $17.43 \pm 1.74$ & $17.12 \pm 1.62$ & $17.59 \pm 1.04$ & $17.01 \pm 1.62$ \\
\hline 0.5 & $20.21 \pm 1.25$ & $17.65 \pm 1.21$ & $23.87 \pm 1.35$ & $18.21 \pm 1.25^{b}$ & $25.35 \pm 1.25^{*}$ & $21.85 \pm 1.41^{\mathrm{a}}$ & $26.21 \pm 1.67^{s}$ & $21.89 \pm 1.68^{\mathrm{a}}$ & $21.11 \pm 1.32$ & $19.25 \pm 1.31$ & $21.21 \pm 1.67$ & $21.89 \pm 1.68$ & $21.21 \pm 1.32$ & $19.35 \pm 1.31$ \\
\hline 1 & $23.15 \pm 1.25$ & $22.1 \pm 1.32$ & $29.29 \pm 1.24^{*}$ & $24.21 \pm 1.54^{\text {*a }}$ & $36.21 \pm 1.57^{*}$ & $29.58 \pm 1.65^{\mathrm{sb}}$ & $32.21 \pm 1.41^{*}$ & $26.09 \pm 1.58^{\star b}$ & $26.21 \pm 1.24 *$ & $24.21 \pm 1.68$ & $26.21 \pm 1.24$ & $24.09 \pm 1.58^{*}$ & $26.21 \pm 1.24^{\mathrm{s}}$ & $24.21 \pm 1.63$ \\
\hline 2 & $26.24 \pm 1.54^{s}$ & $24 \pm 1.26^{*}$ & $35.23 \pm 1.52^{*}$ & $27.21 \pm 1.54^{5 b}$ & $51.89 \pm 1.31^{*}$ & $41.23 \pm 1.71^{\mathrm{e}^{*}}$ & $47.25 \pm 1.43^{*}$ & $33.01 \pm 1.32^{\mathrm{st}}$ & $36.98 \pm 1.31^{*}$ & $28.85 \pm 1.87^{5 b^{*}}$ & $36.25 \pm 1.43^{s}$ & $28.01 \pm 1.32^{s c^{*}}$ & " $36.68 \pm 1.32^{*}$ & $28.71 \pm 1.87^{\mathrm{Sb}^{\mathrm{s}}}$ \\
\hline 3 & $30.57 \pm 1.26$ * & $24.23 \pm 1.73^{\star b}$ & $53.21 \pm 1.87^{*}$ & $41.21 \pm 1.54^{c^{c}}$ & $61.67 \pm 1.56^{5^{+}}$ & $52.21 \pm 1.32^{\mathrm{set}}$ & $51 \pm 1.24^{*}$ & $46.28 \pm 1.63^{a^{*}}$ & $41.21 \pm 1.48^{*}$ & $33.21 \pm 1.65^{* b^{*}}$ & $39 \pm 1.24^{*}$ & $41.28 \pm 1.63^{*}$ & $41.32 \pm 1.48^{*}$ & $33.21 \pm 1.65^{+b^{x}}$ \\
\hline 4 & $39 \pm 1.20^{5 *}$ & $33 \pm 1.63^{5 b^{*}}$ & $59.32 \pm 1.25^{*}$ & $48.21 \pm 1.35^{\mathrm{kt}}$ & $67.35 \pm 1.48^{*}$ & $55.21 \pm 1.54^{\mathrm{c}^{*}}$ & $58.15 \pm 1.63^{5^{*}}$ & $49.35 \pm 1.65^{b^{*}}$ & $47.21 \pm 1.42^{*}$ & $40.21 \pm 1.32^{5 b^{*}}$ & $41.15 \pm 1.63^{*}$ & $40.35 \pm 1.65^{*}$ & $47.33 \pm 1.42^{*}$ & $40.21 \pm 1.32^{5 b^{x}}$ \\
\hline $\begin{array}{l}\text { a: } P<C \\
\therefore: P<C \\
C M C= \\
\text { IR }=\text { Irr } \\
\text { SCE }=S\end{array}$ & $\begin{array}{l}0.05, b: P<0.0 \\
0.05, \$: P<0.0 \\
\text { Carboxymethy } \\
\text { radiation } \\
\text { Syzygium cumil }\end{array}$ & $\begin{array}{l}1, c: P<0.001, \mathrm{n} \\
1,{ }^{*}: P<0.001, \mathrm{n} \\
\text { lcellulose } \\
\text { ni extract }\end{array}$ & $\begin{array}{l}\text { no symbol: no } \\
\text { no symbol : no }\end{array}$ & $\begin{array}{l}\text { on-significant. C } \\
\text { on-significant. W }\end{array}$ & $\begin{array}{l}\text { MC+IR group } \\
\text { When compare }\end{array}$ & $\begin{array}{l}\text { compared to SC } \\
\text { d to Sham-radia }\end{array}$ & $\begin{array}{l}\text { E+IR } \\
\text { tion (O Gy }\end{array}$ & & & & & & & \\
\hline
\end{tabular}

activity ranged between $5.97 \pm 0.05$ to $6.32 \pm 0.02 \mathrm{U} / \mathrm{mg}$ protein in $\mathrm{CMC}+$ sham-irradiation ( $0 \mathrm{~Gy}$ ) mice. Administration of $50 \mathrm{mg} /$ kg SCE orally for five consecutive days did not significantly alter the SOD activity in comparison with $\mathrm{CMC}+$ sham-irradiation group. Exposure of mice to different doses of $\gamma$-radiation resulted in a significant but dose dependent decrease in the SOD activity when compared with CMC + sham-irradiation (Figure 3). The earliest decline in the MnSOD activity was recorded at $0.5 \mathrm{~h}$ post-irradiation and a maximum decrease in the enzyme activity was observed at $2 \mathrm{~h}$ post-irradiation $(2.02 \pm 0.06)$ in the animals exposed to 4 Gy irradiation. The slow recovery in the SOD activity was evident from $4 \mathrm{~h}$ post-irradiation and SOD activity continued to rise up to $24 \mathrm{~h}$ post-irradiation without restoration to shamirradiation level (Figure 4). The comparison among different doses of $\gamma$-radiation revealed that the SOD activity reduced significantly with increasing dose of radiation $(p<0.05 ; 0.01$ or 0.001) depending on the radiation dose and estimation time (Table 2). The pattern of decline in SOD activity after treatment with SCE in SCE+irradiation group was almost identical to that of CMC+irradiation group (Figure 3) except that SCE administration attenuated the radiation-induced decline in the SOD activity significantly ( $p<0.05,0.01$ or 0.001$)$ at all post-irradiation assay times in mouse liver exposed to 0.5 to $4 \mathrm{~Gy}$ (Table 2). Despite this increase, the basal levels of SOD activity could not be restored to normal even by $24 \mathrm{~h}$ post-irradiation (Table 2 ).

\section{Catalase}

The catalase activity was measured in mouse liver at different post-irradiation times and it has been expressed as $\mu \mathrm{mol}$ of $\mathrm{H}_{2} \mathrm{O}_{2}$ reduced $/ \mathrm{min} / \mathrm{mg}$ protein \pm SEM (Figure 5 ). The basal catalase activity in CMC+sham-irradiated ( $0 \mathrm{~Gy}$ ) mice ranged between $29.21 \pm 0.25$ to $29.22 \pm 0.22 \mu \mathrm{mol} / \mathrm{mg}$ protein. Administration of $50 \mathrm{mg} / \mathrm{kg}$ SCE orally for five consecutive days did not induce significant alteration in the catalase activity when compared to basal activity ( $29.21 \pm 0.25$ to $29.22 \pm 0.22$ ). Exposure of mice to different doses of $\gamma$-radiation resulted in a dose dependent reduction in the catalase activity when compared with CMC
+ sham-irradiation (Figure 5). The catalase activity started declining at $0.5 \mathrm{~h}$ post-irradiation and a maximum reduction in the catalase activity was observed at $2 \mathrm{~h}$ post-irradiation $(15.21 \pm 0.75)$ in the livers of mice exposed to 4 Gy (Figure 6). Thereafter the catalase activity increased gradually until $24 \mathrm{~h}$ post-irradiation however, normal levels could not be restored even by $24 \mathrm{~h}$ post-irradiation (Figure 6 ). The catalase activity was significantly $(p<0.001)$ lower when compared to CMC+shamirradiation. The comparison among different doses of $\gamma$-radiation revealed that the catalase activity did reduce significantly with increasing dose of radiation $(P<0.05 ; 0.01$ or 0.001$)$ depending on the irradiation dose and estimation time (Table 3). The pattern of decline in catalase activity after treatment with SCE in SCE+irradiation group was similar to that of CMC+irradiation group (Figure 5), except that SCE administration reduced the radiation-induced decline in the catalase activity significantly ( $p$ $<0.05,0.01$ or 0.001 ) at all post-irradiation times after exposure to 0.5 to 4 Gy (Table 3 ). However, the catalase activity could not be restored to basal level even at $24 \mathrm{~h}$ post-irradiation (Table 3 ).

\section{Lipid peroxidation}

The CMC+sham-irradiation group showed a minimum lipid peroxidation $(17.23 \pm 1.25$ nanomoles of MDA/ mg protein) which did not show any change with estimation time (Figure 7). Administration of mice with $50 \mathrm{mg} / \mathrm{kg}$ SCE orally once daily for five consecutive days did not significantly alter the lipid peroxide levels when compared to control (0 Gy). Exposure of animals to different doses of $\gamma$-radiation caused a significant $(p<0.05$, 0.01 or 0.001 ) rise in the lipid peroxidation when compared to $\mathrm{CMC}+$ sham-irradiation group (Figure 7). An earliest increase in lipid peroxides was recorded at $0.5 \mathrm{~h}$ post-irradiation and a maximum rise $(67.35 \pm 1.48)$ in the lipid peroxidation was detected at $2 \mathrm{~h}$ post-irradiation. Thereafter the level of lipid peroxides gradually declined until $24 \mathrm{~h}$ post-irradiation without restoration to normal levels (Figure 8). The comparison among various doses of $\gamma$-radiation showed that the lipid peroxide levels were significantly higher with increasing dose of radiation and 

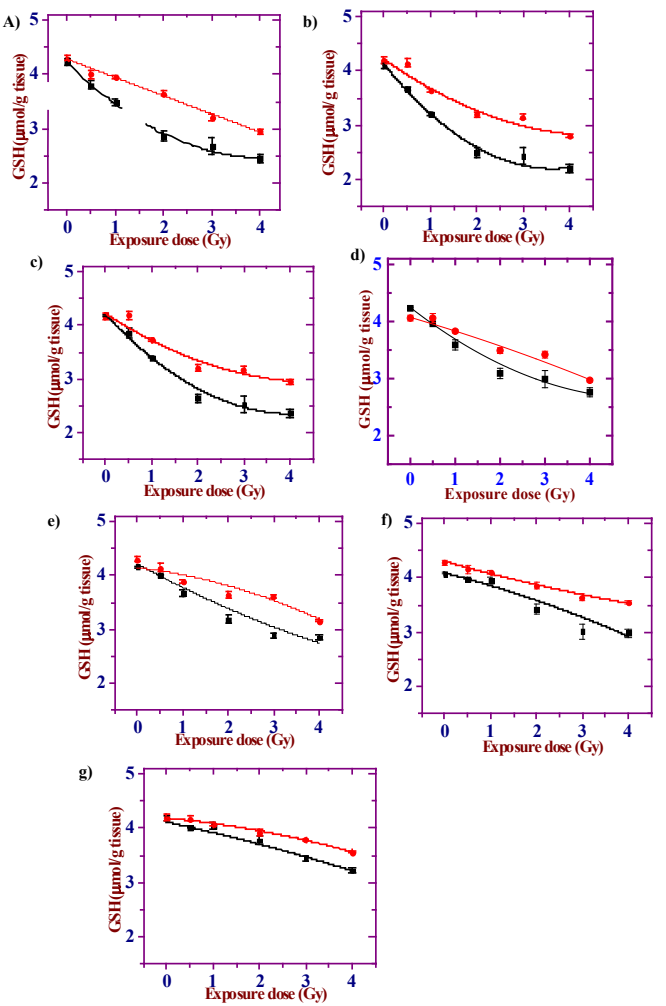

Figure 1: Effect of $50 \mathrm{mg} / \mathrm{kg}$ body weight of SCE on the glutathione (GSH) concentration in the livers of mice exposed different doses of gamma radiation. a: $0.5 \mathrm{~h}, \mathrm{~b}: 1 \mathrm{~h}, \mathrm{c}: 2 \mathrm{~h}, \mathrm{~d}: 4 \mathrm{~h}, \mathrm{e}: 8 \mathrm{~h}, \mathrm{f:} 12 \mathrm{~h}$ and g: $24 \mathrm{~h}$ post-irradiation. Squares: CMC+irradiation and circles: SCE+irradiation. CMC=Carboxymethylcellulose SCE: Syzygium cumini Extract
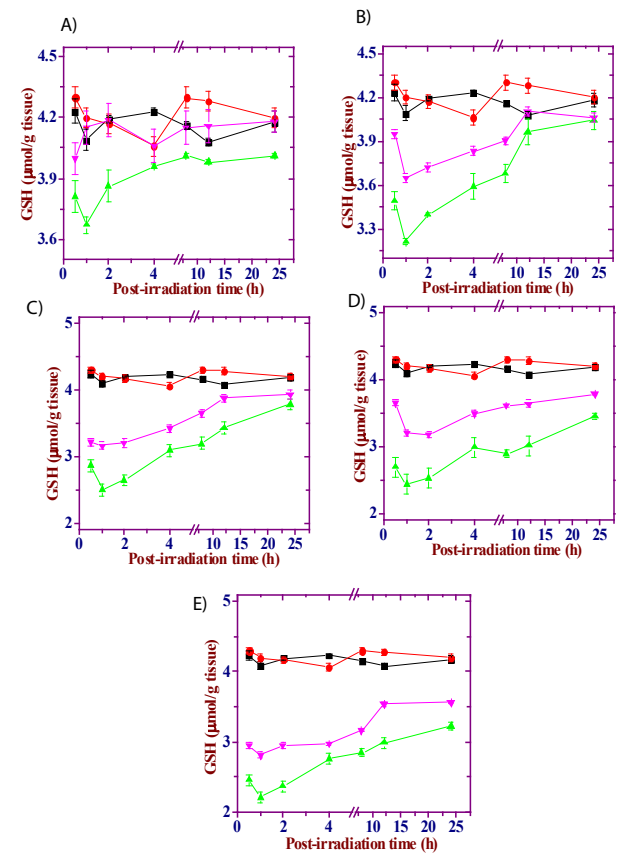

Figure 2: Effect of $50 \mathrm{mg} / \mathrm{kg}$ body weight of SCE on the glutathione (GSH) concentration in the livers of mice exposed to different doses of gamma radiation. a: 0.5Gy, b: 1Gy, c:2Gy, d:3Gy, e:4Gy. Squares: Cmc+sham-irradiation (0 Gy); Circles: Sce+ sham-irradiation (0 Gy); Up trinagles: Cmc+irradiation and Down triangles: SCE+irradiation.

CMC: Carboxymethylcellulose

SCE: Syzygium Cumini Extract 

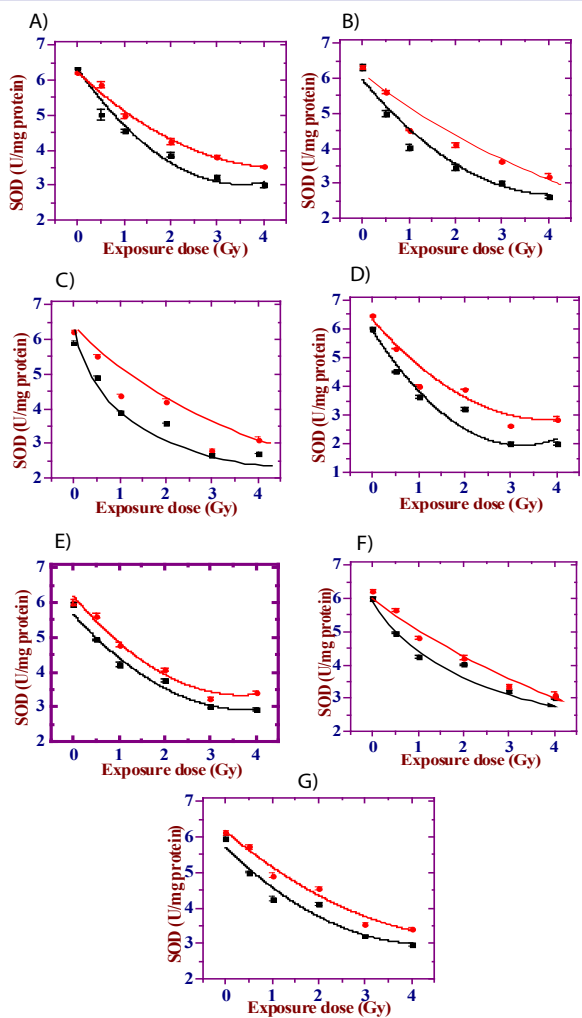

Figure 3: Effect of $50 \mathrm{mg} / \mathrm{kg}$ body weight of SCE on the Superoxide Dismutase (SOD) activity in the livers of mice exposed different doses of gamma radiation. a: $0.5 \mathrm{~h}, \mathrm{~b}: 1 \mathrm{~h}, \mathrm{c:} 2 \mathrm{~h}, \mathrm{~d}: 4 \mathrm{~h}, \mathrm{e}: 8 \mathrm{~h}, \mathrm{f}: 12 \mathrm{~h}$ and g: $24 \mathrm{~h}$ post-irradiation. Squares: CMC+irradiation and circles: SCE+irradiation.

CMC: Carboxymethylcellulose

SCE: Syzygium Cumini Extract
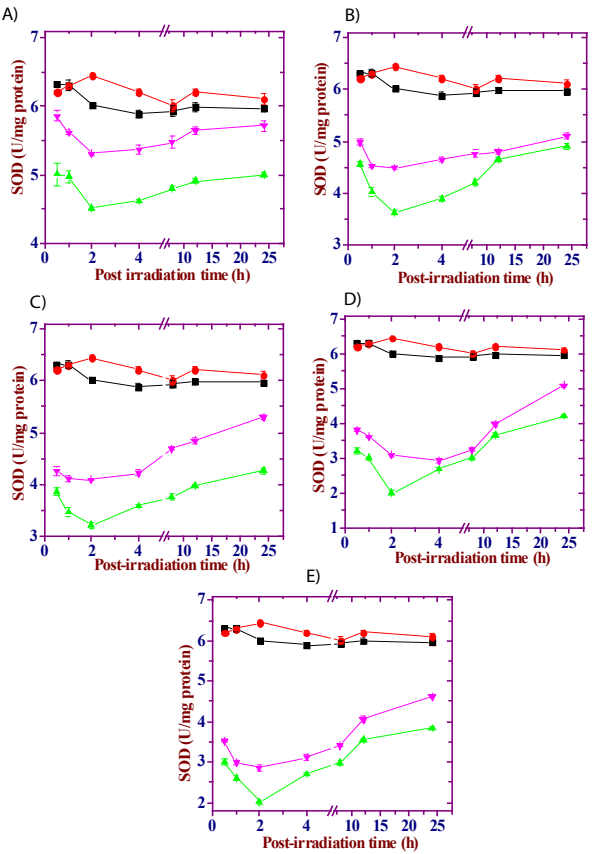

Figure 4: Effect of $50 \mathrm{mg} / \mathrm{kg}$ body weight of SCE on the Superoxide Dismutase (SOD) activity in the livers of mice exposed different doses of gamma radiation. a: $0.5 \mathrm{~Gy}$, b: $1 \mathrm{~Gy}$, c: $2 \mathrm{~Gy}$, d: 3Gy, e: 4Gy. Squares: CMC+sham-irradiation (0 Gy); Circles: SCE+ sham-irradiation (0 Gy); Up trinagles: CMC+irradiation and Down triangles: SCE+irradiation.

CMC: Carboxymethylcellulose

SCE: Syzygium Cumini Extract 

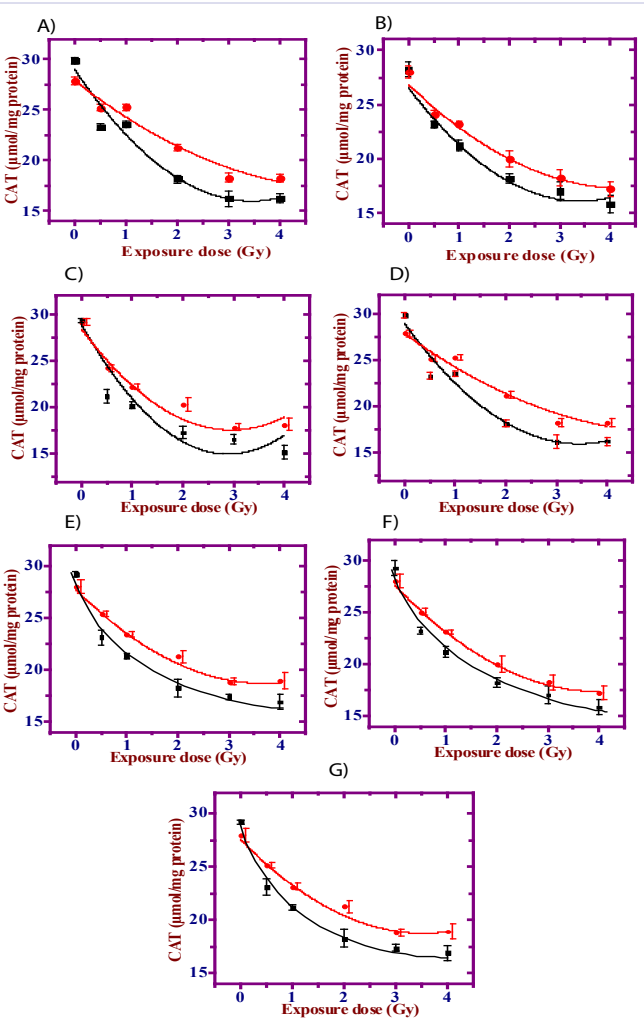

Figure 5: Effect of $50 \mathrm{mg} / \mathrm{kg}$ body weight of SCE on the catalase (CAT) activity in the livers of mice exposed different doses of gamma radiation. a: $0.5 \mathrm{~h}$, b: $1 \mathrm{~h}, \mathrm{c}: 2 \mathrm{~h}, \mathrm{~d}: 4 \mathrm{~h}, \mathrm{e}: 8 \mathrm{~h}, \mathrm{f}: 12 \mathrm{~h}$ and g: $24 \mathrm{~h}$ post-irradiation. Squares: CMC+irradiation and circles: SCE+irradiation.

CMC: Carboxymethylcellulose

SCE: Syzygium Cumini Extract
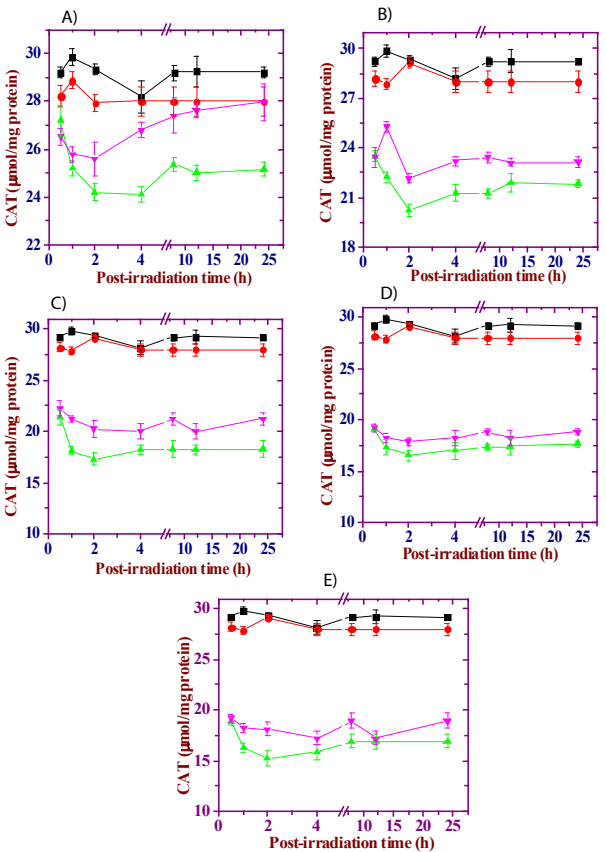

Figure 6: Effect of $50 \mathrm{mg} / \mathrm{kg}$ body weight of SCE on the catalase (CAT) activity in the livers of mice exposed different doses of gamma radiation. a: 0.5Gy, b:1Gy, c:2Gy, d:3Gy, and e:4Gy. Squares: CMC+sham-irradiation (0 Gy); Circles: SCE+ sham-irradiation (0 Gy); Up trinagles: CMC+irradiation and Down triangles: SCE+irradiation.

CMC: Carboxymethylcellulose

SCE: Syzygium Cumini Extract 

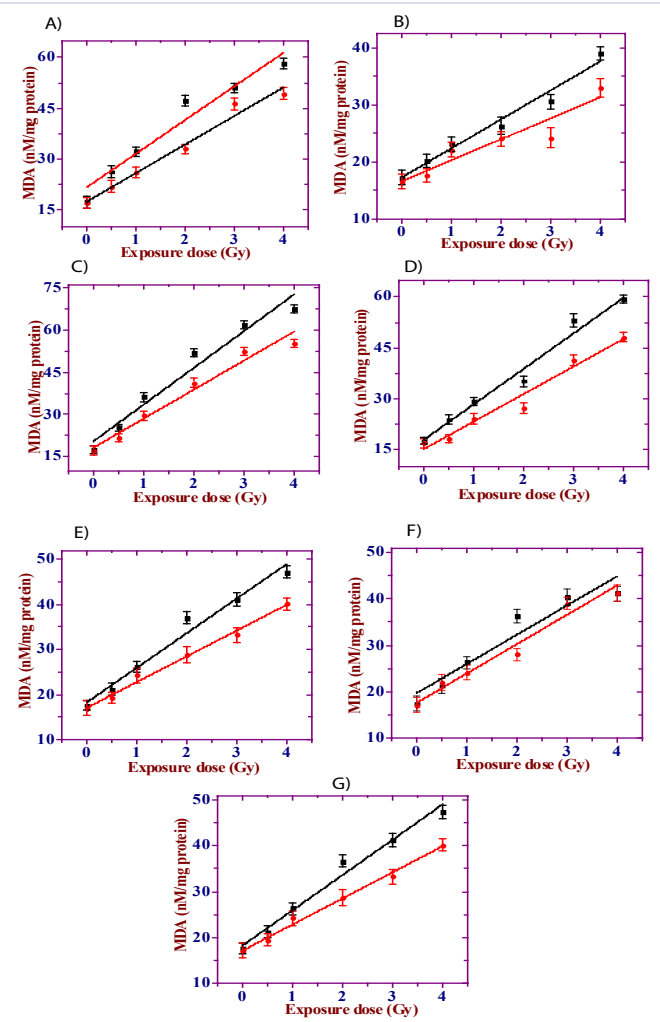

Figure 7: Effect of $50 \mathrm{mg} / \mathrm{kg}$ body weight of SCE on the lipid peroxidation in the livers of mice exposed different doses of gamma radiation. a: $0.5 \mathrm{~h}$, b: $1 \mathrm{~h}, \mathrm{c:2h}, \mathrm{d}: 4 \mathrm{~h}, \mathrm{e}: 8 \mathrm{~h}, \mathrm{f}: 12 \mathrm{~h}$ and g: $24 \mathrm{~h}$ post-irradiation. Squares: CMC+irradiation and circles: SCE+irradiation.

CMC: Carboxymethylcellulose

SCE: Syzygium Cumini Extract
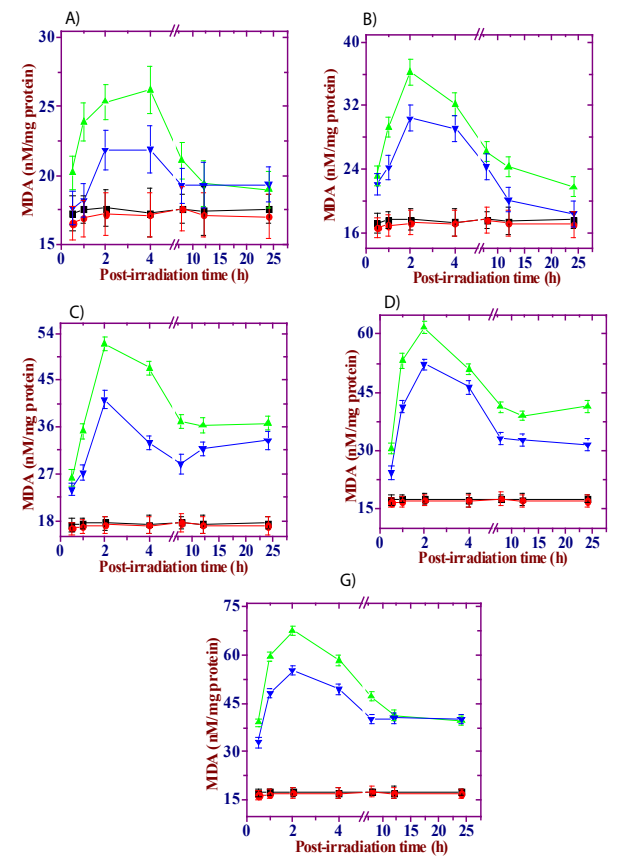

Figure 8: Effect of $50 \mathrm{mg} / \mathrm{kg}$ body weight of SCE on the lipid peroxidation in the livers of mice exposed different doses of gamma radiation. a: $0.5 \mathrm{~Gy}$, b:1Gy, c:2Gy, d:3Gy, e:4Gy. Squares: CMC+sham-irradiation (0 Gy); Circles: SCE+ sham-irradiation (0 Gy); Up trinagles: CMC+irradiation and Down triangles: SCE+irradiation.

CMC: Carboxymethylcellulose

SCE: Syzygium Cumini Extract

Citation: Jagetia GC, Shetty PC (2016) Augmentation of Antioxidant Status in the Liver of Swiss Albino Mice treated with Jamun 


\section{Augmentation of Antioxidant Status in the Liver of Swiss Albino Mice treated with Jamun (Syzygium Cumini, Skeels) Extract before Whole Body Exposure to Different Doses of $\gamma$-Radiation}

also with the immediate preceding dose $(p<0.05,0.01$ or 0.001$)$ depending on the post-irradiation time and irradiation dose (Table 4). Administration of SCE before irradiation resulted in a significant reduction in the lipid peroxidation when compared to $\mathrm{CMC}+$ irradiation group at all the post-irradiation times. The pattern of increase in lipid peroxide level after treatment with SCE in SCE+irradiation group was similar to that of $\mathrm{CMC}+$ irradiation group (figure 7) except that the SCE administration inhibited the radiation-induced lipid peroxidation significantly $(p<0.05,0.01$ or 0.001) at all post-irradiation times after exposure to 0.5 to $4 \mathrm{~Gy}$ (Table 4). Despite a significant decline, the level of lipid peroxide did not reach basal level even by $24 \mathrm{~h}$ post-irradiation.

\section{Discussion}

It a well-established fact that exposure to ionizing radiations results in a complex set of responses, whose onset, nature, and severity is a function of both radiation quality and total radiation dose received by the organism $[42,43]$. Since the body contains more than $75 \%$ water, ionizing radiations principally interact with water molecules abundant in the cellular milieu and generate different types of free radicals $[9,44]$. These radiation-induced free radicals are mainly responsible for the induction of oxidative stress in the body. The exposure to ionizing radiation negatively alters the oxidant status in different tissues of the body [45]. The increased oxidative stress by ionizing radiation has been implicated in the induction of cancer, cardiovascular, liver, lung and neurological disorders [44-49]. The use of phytoceuticals may be able to reduce the risk of radiation-induced oxidative stress. Plants have been used by humans throughout their history in different cultures for health benefits and curing diseases and have been considered nontoxic. Even today, more than $80 \%$ of the world's population is dependent on plants for handling their health related problems [50]. The biologic origin of phytoceuticals make them more attractive for the investigation as antioxidants as their biologic origin makes them more biocompatible than the synthetic drugs [6]. Therefore, present study was undertaken to elucidate the effect of SCE on the radiation-induced alteration in the antioxidant status in mouse liver exposed to different doses of $\gamma$-radiation.

The radiation-induced damage in the living cells is a consequence of generation of oxygen-derived free radicals including superoxide anion and hydrogen peroxide owing to radiolysis of water $[9,44]$. Once generated these reactive oxygen species react with various important biomolecules inflicting lesions in different types of cells [11]. These free radicals play an important role in the production of indirect biological damage induced by low LET ionizing radiations [51]. Organisms possess comprehensive and integrated endogenous enzymatic repair systems to cope up with ROS induced-damage. Glutathione (GSH), vitamin $\mathrm{E}$ and $\mathrm{C}$, -carotene and uric acid are some of the important non-enzymatic antioxidants that are taken up with food or synthesized endogenously, whereas SOD ( $\mathrm{Cu} \mathrm{Zn}$, or $\mathrm{Mn}$ ), catalase, and glutathione peroxidase (GSHpx) represent endogenous enzymatic antioxidants that will neutralize or mitigate effect of oxidative stress induced by physical or chemical agents [52]. Usually ROS responses after irradiation are diminished by a number of cellular defenses including GSH, GSHpx, catalase, SOD etc. $[5,7,8,19,53]$. The enzymes including superoxide dismutase (SODs) and glutathione peroxidase (GPx) help to neutralize the radiation-induced superoxide anion or hydrogen peroxide $\left(\mathrm{H}_{2} \mathrm{O}_{2}\right)$ and defend cells from radiation-induced oxidative stress.

Glutathione is one of the most prevalent intracellular thiols that exert its antioxidant action by scavenging hydroxyl radicals and singlet oxygen, and protect the cell against oxidative stress induced by them [54]. GSH offers protection against oxygenderived free radicals and cellular lethality following exposure to ionizing radiation [55]. The alleviation of GSH leads to formation of reactive oxygen species and oxidative stress that affect functional as well as structural integrity of cell and organelle membranes [56]. In the normal conditions, the cells are intact and healthy and GSH is restored by synthesis [54] however, availability of GSH after irradiation may decrease due to reduced GSH synthesis enhanced efflux or inefficient reduction of GSSG [57]. Moreover, GSH may be also utilized to neutralize the radiation-induced free radicals and in the formation of thiyl radicals that associate to produce GSSG [58]. This explains a dose dependent reduction in the GSH concentration after exposure to 0 to $4 \mathrm{~Gy}$ and its maximum depletion at $1 \mathrm{~h}$ post-irradiation in the present study. These results are consistent with earlier reports where irradiation has been found to reduce GSH concentration $[5,7,20,59]$. A number of natural or synthetic radioprotectors can alter the balance of endogenous protective systems, such as glutathione and antioxidant enzyme systems after irradiation, and reduce the effect of radiation $[5,7,20,22]$. Administration of jamun extract reduced the radiation-induced decline in the GSH concentration, which could be partially due to abatement of radiation-induced free radicals or upregulation of GSH synthesis. Likewise, ascorbic acid, naringin, Agele marmelos, Zingiber officinale, Phyllanthus amarus, Nigella sativa, curcumin, and hesperidin have been reported to increase the GSH concentration after irradiation [5,7,19,20,22,60-62].

The enzyme superoxide dismutase eliminates superoxide anion, which forms part of the $\mathrm{H}_{2} \mathrm{O}_{2}$ in cells. Irradiation of mice resulted in a dose dependent reduction in the SOD activity that was below spontaneous level even after $24 \mathrm{~h}$ post-irradiation. Irradiation has been reported to decrease superoxide dismutase activity in vivo and in vitro earlier $[5,7,19,20,22,59,63]$. Treatment of mice with SCE caused a significant elevation in the liver SOD activity after irradiation that would have helped in the efficient neutralization of radiation-induced superoxide anion and thus reduced the radiation-induced oxidative stress. An identical effect has been observed earlier in mice treated with $\alpha$ - tocopherol, ascorbic acid, naringin, curcumin and hesperidin before $\gamma$-irradiation $[5,7,19,20,22,63]$. Our observations are also supported by the reports that indicate that over expression of Mn-SOD protected cells from the damage induced by reactive oxygen species [64].

Catalase is one of the important enzymes, which is involved in the conversion of highly reactive and toxic $\mathrm{H}_{2} \mathrm{O}_{2}$ into nontoxic byproducts such as water and molecular oxygen. Irradiation of mice with different doses of gamma radiation resulted in a 
dose dependent decline in catalase activity in the mice liver. This decline may to due to the participation of catalase into the detoxification of $\mathrm{H}_{2} \mathrm{O}_{2}$ generated after irradiation. Irradiation has been reported to reduce the activity of enzyme catalase in various tissues $[5,19,22]$. Administration of SCE caused a significant rise in the activity of catalase in the mouse liver and a maximum elevation was observed at $2 \mathrm{~h}$ post-irradiation. This increase in catalase by SCE may have helped to abate the radiation-induced generation of $\mathrm{H}_{2} \mathrm{O}_{2}$ and thus protecting the mouse against the deleterious effect of radiation. Likewise, catalase has been reported to be elevated after treatment with various radioprotectors in the irradiated animals earlier $[5,19$, $22,59,63]$.

Lipid peroxidation is another important consequence of irradiation and is one of the measures to determine the cellular toxicity [65]. Earlier studies have indicated that the peroxidation of membrane lipids might be the main cause of membrane damage induced by radiation [66], therefore studies on lipid peroxidation can provide valuable information about the damage caused by the ionizing radiations. The exposure of animals to different doses of $\gamma$-radiation increased lipid peroxidation in a dose dependent manner in mouse liver and this rise in lipid peroxidation may be due to the attack of radiation-induced free radicals on the fatty acid component of membrane lipids, that may lead to cell death $[5,7,19,22,67,68]$. A similar increase in radiation-induced lipid peroxidation has been reported earlier $[5,7,19,22]$. Administration of mice with SCE reduced the formation of lipid peroxides. Likewise, ascorbic acid, melatonin, and other botanicals including ginger, Agele marmelos, Nigella sativa, naringin, mangiferin, curcumin and hesperidin have also been reported to protect the mice against gamma radiation by elevating glutathione levels and reducing lipid peroxidation both in vivo and in vitro $[5,7,19,20,22]$. The flavonoids quercetin, myricetin, and kaempferol are known to activate glutathionesynthesizing enzyme [69] that would have helped to increase the GSH concentration in the present study and also reduce lipid peroxidation. The increase in GSH, catalase, and SOD by SCE may have neutralized the reactive oxygen species and thus protected against the radiation-induced lipid peroxidation after exposure to different doses of $\gamma$-radiation.

The exact mechanism by which the jamun extract has up regulated the antioxidant status is not known. However, it is speculated that pretreatment of mice with jamun extract may have up regulated the transcriptional activation of Nrf2 gene, that may have stimulated the activation of various genes related to GSH, SOD, catalase and increasing their synthesis and thus reduced the negative effect of radiation on the antioxidant status. Ionizing radiation has been reported to down regulate the Nrf2 gene earlier [70].

The present study demonstrates that SCE pretreatment elevates the GSH, SOD and catalase in mouse liver, and this increase in antioxidants and reduced lipid peroxidation may be due to the transcriptional activation of Nrf2 gene in the irradiated mouse liver leading to its radio protective activity.

\section{Acknowledgements}

The authors are thankful to Dr. M.S. Vidyasagar, Professor and Head, and Dr. J.G.R. Solomon, Department of Radiotherapy and Oncology, Kasturba Medical College Hospital, Manipal, India for providing the necessary irradiation facilities and dosimetric calculations, respectively.

\section{Conflict of interest statement}

Authros do not have any conflict of statement to declare.

\section{References}

1. Møller AP, Mousseau TA. Biological consequences of Chernobyl: 20 years on. Trends Ecol Evol. 2006;21(4):2007.

2. I.I. Kryshev. Radioactive contamination of aquatic ecosystem following the Chernobyl accident. J. Environm. Radioact. 1995;27(3):207-219. Doi:10.1016/0265-931X(94)00042-U.

3. Steen TY, Mousseau T. Outcomes of Fukushima: Biological Effects of Radiation on Nonhuman Species. J Hered. 2014;105(5):702-3. Doi:10.1093/jhered/esu049.

4. Turner ND, Braby LA, Ford J, Lupton JR. Opportunities for nutritional amelioration of radiation-induced cellular damage. Nutrition.2002;18(10):904-12.

5. Jagetia GC, Reddy TK. Modulation of radiation-induced alteration in the antioxidant status of mice by naringin. LifeSci.2005;77(7):780-94.

6. C Jagetia G. Radioprotective potential of plants and herbs against the effects of radiation. J Clin Biochem Nutr. 2007;40(2):74-81. Doi:10.3164/jcbn.40.74.

7. G.C. Jagetia, K.V.N.M. Rao Hesperidin, A Citrus Bioflavonoid Reduces the Oxidative Stress in the Skin of Mouse Exposed to Partial Body $\gamma$-Radiation. Transcriptomics 3(2) (2015). Doi:10.4172/23298936.1000111.

8. Riley PA. Free Radicals in Biology: Oxidative stress and the effect of ionizing radiation. Int J Radiat Biol. 1994;65(1):27-33.

9. S. LeCaër,Waterradiolysis: influence of oxide surfaces on $\mathrm{H} 2$ production under ionizing radiation. Water (20734441);2011;3(1):235.

10. Dainiak N, Tan BJ. Utility of biological membranes as indicators for radiation exposure: alterations in membrane structureandfunctionovertime.StemCells.1995;13Suppl1:142-52.

11. Lomax ME, Folkes LK, O’Neill P. Biological consequences of radiationinduced DNA damage: relevance to radiotherapy.ClinOncol(RCollRadi ol).2013;25(10):578-85.Doi:10.1016/j.clon.2013.06.007.

12. O. Desouky N. Ding G. Zhou. Targeted and non-targeted effects of ionizing radiation. J. Radiat. Res. Appl. Sci. 8 2015;247-254.

13. Shah DJ, Sachs RK, Wilson DJ. Radiation-induced cancer: a modern view. Br J Radiol. 2012;85(1020):e1166-73. Doi: 10.1259/bjr/25026140.

14. B. Halliwell, J.M.C. Gutteridge. Free radicals in biology and medicine, second ed. Clarendon Press, Oxford. 1989.

15. Burns J, Gardner PT, Matthews D, Duthie GG, Lean ME, Crozier A. Extraction of phenolics and changes in antioxidant activity of red wines during vinification. J Agric Food Chem. 2001;49(12):5797-808.

16.Giustarini D, Dalle-Donne I, Tsikas D, Rossi R. Oxidative stress and human diseases: Origin, link, measurement, mechanisms, and biomarkers. Crit Rev Clin Lab Sci. 2009;46(5-6):241-81. Doi: $10.3109 / 10408360903142326$. 
17. Kryston TB, Georgiev AB, Pissis P, Georgakilas AG. Role of oxidative stress and DNA damage in human carcinogenesis. MutatRes.2011;711(1-2):193-201.Doi:10.1016/j. mrfmmm.2010.12.016.

18. Marklund SL, Westman NG, Roos G, Carlsson J. Radiation resistance and the CuZn superoxide dismutase, Mn superoxide dismutase, catalase, and glutathione peroxidase activities of seven human cell lines. Radiat Res. 1984;100(1):115-23.

19. Chandra Jagetia G, Rajanikant GK, Rao SK, Shrinath Baliga M. Alteration in the glutathione, glutathione peroxidase, superoxide dismutase and lipid peroxidation by ascorbic acid in the skin of mice exposed to fractionated $\gamma$-radiation. Clin Chim Acta. 2003;332(1-2):111-21.

20. Jagetia GC, Rajanikant GK. Curcumin Stimulates the Antioxidant Mechanisms in Mouse Skin Exposed to Fractionated $\gamma$-Irradiation.Anti oxidants(Basel).2015;4(1):25-41.Doi:10.3390/antiox4010025.

21. Halliwell B. Biochemistry of oxidative stress. Biochem Soc Trans. 2007;35(Pt 5):1147-50.

22. Jagetia GC, Ravikiran PB. Acceleration of Wound Repair and Regeneration by Nigella Sativa in the Deep Dermal Excision Wound of Mice Whole Body Exposed to Different Doses of $\gamma$-radiation. Am. Res. J. Med. Surg. 2015;1(3):1-17.

23. Lal BN, Choudhuri KD. Observations on Momordica charantia Linn, and Eugenia jambolana Lam. as oral antidiabetic remedies. Indian J. Med. Res. 2(1968):161.

24. Chandrasekaran $M$, Venkatesalu V. Antibacterial and antifungal activity of Syzygium jambolanum seeds. J Ethnopharmacol.2004;91(1):105-8.

25. Muruganandan S, Pant S, Srinivasan K, Chandra S, Tandan SK, La $\mathrm{J}$, et al. Inhibitory role of Syzygium cumini on autacoid-induced inflammationinrats. Indian J Physiol Pharmacol. 2002; 46(4):482-6.

26. Ramirez RO, Roa CC Jr. The gastroprotective effect of tannins extracted from duhat (Syzygium cumini Skeels) bark on $\mathrm{HCl}$ / ethanol induced gastric mucosal injury in Sprague-Dawley rats. Clin Hemorheol Microcirc. 2003;29(3-4):253-61.

27. Ravi K, Rajasekaran S, Subramanian S. Antihyperlipidemic effect of Eugenia jambolana seed kernel on streptozotocin induced diabetesinrats. Food Chem Toxicol. 2005; 43(9): 1433-9.

28. A. Banerjee, N. Dasgupta, B De. In vitro study of antioxidant activity of Syzygium cumini fruit. Food Chem. 90(2005) 727-733.

29. Braga FG, Bouzada ML, Fabri RL, de O Matos M, Moreira FO, Scio E, et al. Antileishmanial and antifungal activity of plantsused intraditional medicine in Brazil. J Ethnopharmacol. 2007;111(2):396-402.

30. S.B. Swami, N.S.J. Thakor, M.M. Patil, P.M. Haldankar Jamun (Syzygium cumini (L.)): A Review of its food and medicinal uses. Food Nutr. Sci. 2012;1100-1117.

31. Chagas VT, França LM, Malik S, Paes AM. Paes Syzygium cumini (L.) skeels: a prominent source of bioactive molecules against cardiometabolic diseases. Front Pharmacol. 2015;6:259. Doi:10.3389/ fphar.2015.00259.

32.Jagetia GC, Shetty PC, Vidyasagar MS. Inhibition of radiation-induced DNA damage by jamun, Syzygium cumini, in the cultured splenocytes of mice exposed to different doses of $\gamma$-radiation. Integr Cancer Ther. 2012;11(2):141-53. Doi:10.1177/1534735411413261.

33. Jagetia GC, Baliga MS. Syzygium cumini (Jamun) reduces the radiationinduced DNA damage in the cultured humanperipheralbloodlymphoc ytes:apreliminarystudy.Toxicol Lett. 2002;132(1):19-25.
34. Jagetia GC, Baliga MS. Evaluation of the radioprotective effect of the leaf extract of Syzygium cumini (Jamun) in miceexposedtoalethaldoseofgamma-irradiation.

Nahrung. 2003;47(3):181-5.

35. Jagetia GC, Baliga MS, Venkatesh P. Influence of seed extract of Syzygium cumini (jamun) on mice exposed to differentdosesof $\gamma$ radiation.JRadiatRes.2005;46(1):59-65.

36. G.C. Jagetia, P.C. Shetty, M.S.Vidyasagar.Treatment of mice with leaf extract of jamun (Syzygium cumini Linn. Skeels) protects against the radiation-induced damage in the intestinal mucosa of mice exposed to different doses of $\gamma$-radiation. Pharmacol. Onl. 1;2008;169-195.

37. Suffness M, Douros J. Drugs of plant origin. Meth. Cancer Res. 1979;26:73-126.

38. Moron MS, Depierre JW, Mannervik B. Levels of glutathione, glutathione reductase and glutathione S-transferase activities in rat lung and liver. Biochim Biophys Acta. 1979;582(1):67-78.

39. Aebi H. atalaseinvitro. In: Packer, L. (Ed.), MethodsEnzymol.1984;105:121-6.

40. Fried R. Enzymatic and non-enzymatic assay of superoxide dismutase. Biochimie. 1975;57(5):657-60.

41. Buege JA, Aust SD. Microsomallipidperoxidation. Methods Enzymol.1978;52:302-10.

42. Feinendegen LE, Pollycove M, Sondhaus CA. Responses to Low Doses of Ionizing Radiation in Biological Systems. Non linearity Biol Toxicol Med. 2004;2(3):143-71. Doi:10.1080/15401420490507431.

43. Blakely EA. Taylor lecture on radiation protection and measurments: what makes particle radiation so effective? Health Phys.2012;103(5): 508-28. Doi: 10.1097/HP.0b013e31826a5b85.

44. Kreipl MS, Friedland W, Paretzke HG. Time- and space resolved Monte Carlo study of water radiolysis for photon, electron and ion irradiation. Radiat Environ Biophys. 2009;48(1):11-20. Doi: 10.1007/ s00411-008-0194-8.

45.Z. Hui, Z. Naikun, Z. Rong, L. Xiumin,C. Huifang. Effect of ionizing radiation bio-oxidase activities in cytoplasm of mouse blood and liver cells. Chin J Radiol Med Prot.1996;16 (3):179-82.

46. L. Zhang H. Yang Y. Tian Radiation-induced cognitive impairment. Therap. Targets Neurol. Dis. 2 (2015) e837.

47. Mattonen SA, Tetar S, Palma DA, Louie AV, Senan S, Ward AD. Imaging texture analysis for automated prediction of lung cancer recurrence after stereotactic radiotherapy.J Med Imaging (Bellingham). 2015;2(4):041010. Doi: 10.1117/1.JMI.2.4.041010.

48. Benson R, Madan R, Kilambi R, Chander S. Radiation induced liver disease: A clinical update. J Egypt Natl Canc Inst.2016;28(1):7-11. Doi:10.1016/j.jnci.2015.08.001.

49. Gujral DM, Lloyd G, Bhattacharyya S. Radiation-induced valvular heart disease. Heart. 2015. pii: heartjnl-2015-308765. Doi:10.1136/ heartjnl-2015-308765.

50. L.Shantabi, G.C.Jagetia, Vabeiryureilai M. and Lalrinzuali K. Phytochemical Screening of Certain Medicinal Plants of Mizoram, India and their Folklore Use. Journal Biodiversity, Bioprospecting and Development.2014;1(4).

51.J.E. Biaglow, M.E. Varnes, E.R Epp, E.P Clark. Anticarcinogenesis and radiation protection, Plennum Press, New York.1987.

52. Carocho M, Ferreira IC. A review on antioxidants, prooxidants and related controversy: Natural and synthetic compounds, screening and 
analysis methodologies and future Perspectives. Food Chem Toxicol. 2013;51:15-25. Doi: 10.1016/j.fct.2012.09.021.

53. Peltola V, Parvinen M, Huhtaniemi I, Kulmala J, Ahotupa M. Comparison of effects of 0.5 and 3.0 Gy X-irradiation on lipid peroxidation and antioxidant enzyme function in rat testis and liver. J Androl. 1993;14(4):267-74.

54. MeisterA, Anderson ME.Glutathione. AnnuRevBiochem. 1983;52:71160.

55. Hall EJ, Giaccia AJ. Radiobiology for the Radiologist. Lippincott Williams \& Wilkins: Philadelphia USA; 2012.

56. Leong PK, Ko KM. Induction of the Glutathione Antioxidant Response/ Glutathione Redox Cycling by Nutraceuticals: Mechanism of Protection against Oxidant-induced Cell Death. Curr Trends Nutraceut. 2016;1:12 .

57. Jones DP. The Role of Oxygen Concentration in oxidative stress: hypoxic and hyperoxic models. In: Sies, H. (Ed), Oxidative Stress. Academic Press. New York: 1985;152-196.

58. Bogdanovic V, Bogdanovic G, Grubor-Lajsic G, Rudic A, Baltic V. Effect of irradiation on enzymes of antioxidant defense system in $\mathrm{L}$ 929 cell culture in the presence of $\alpha$-tocopherol acetate. Arch Oncol. 2000;8(4):157-59.

59. Navarro J, Obrador E, Pellicer JA, Aseni M, Viña J, Estrela JM. Blood glutathione as an index of radiation-induced oxidative stress in mice and humans. Free Radic Biol Med.1997;22(7):1203-9.

60. Han Y, Son SJ, Akhalaia M, Platonov A, Son HJ, Lee KH, et al. Modulation of radiation-induced disturbances of antioxidant defense systems by ginsan. Evid Based Complement Alternat Med. 2005;2(4):529-36.

61. Jagetia GC, Baliga MS, Venkatesh P, Ulloor JN. Influence of ginger rhizome (Zingiber officinale Rosc) on survival, glutathione and lipid peroxidation in mice after whole-body exposure to gamma radiation. Radiat Res. 2003 Nov;160(5):584-92.
62. Jagetia GC, Venkatesh P, Baliga MS. Evaluation of the radio protective effect of bael leaf (Aegle marmelos) extract in mice. Int J Radiat Biol. 2004;80(4):281-90.

63. Kumar KB, Kuttan R. Protective effect of an extract of Phyllanthus amarus against radiation-induced damage in mice. JRadiatRes. 2004;45(1):133-9.

64. Hirose K, Longo DL, Oppenheim JJ, Matsushima K. Over expression of mitochondrial manganese superoxide dismutase promotes the survival of tumor cells exposed to interleukin-1, tumor necrosis factor, selected anticancer drugs, and ionizing radiation. The FASEB J.1993;7(2):361-368.

65. Girotti AW. Lipid hydroperoxide generation, turnover, and effector action in biological systems. J Lipid Res. 1998;39(8):1529-42.

66. Wills ED, Wilkinson AE. Effects of Irradiation on Subcellular Components. Int J Radiat Biol Relat Stud Phys Chem Med.1970;17(3):229-36.

67. Raleigh JA, Kremers W, Gaboury B. Dose-rate and oxygen effects in models of lipid membranes: linoleic acid. Int J Radiat Biol Relat Stud Phys Chem Med. 1977;31(3):203-13.

68. Jagetia GC, Venkatesha VA. Effect of mangiferin on radiationinduced micronucleus formation in cultured human peripheralbloodlymphocytes.EnvironMolMutagen.2005;46(1):12-21.

69. Moskaug JØ, Carlsen H, Myhrstad MC, Blomhoff R. Polyphenols and glutathione synthesis regulation. Am J Clin Nutr.2005;81(1):277S283S.

70. Khan A, Manna K, Das DK, Kesh SB, Sinha M, Das U, et al. Gossypetin ameliorates ionizing radiation-induced oxidative stress in mice liver-a molecular app. Free Radic Res. 2015;49(10):1173-86. Doi: 10.3109/10715762.2015.1053878. 